[溶接学会論文集 第 33 巻 第 1 号 $\quad$ p. 29-33 (2015)]

\title{
Co 基合金肉盛層の微細組織に及ぼす摩擦攪拌プロセスの影響*
}

\author{
北村 優介**，森貞 好昭***，藤井 英俊***，水野 雅****，阿部 源隆****
}

Effect of friction stir processing on microstructure of laser clad cobalt based alloy*

\begin{abstract}
by KITAMURA Yusuke**, MORISADA Yoshiaki***, FUJII Hidetoshi***, MIZUNO Tadashi**** and ABE Genryuu ${ }^{* * * *}$
\end{abstract}
\begin{abstract}
The microstructural refinement of cobalt based alloy (Stellite NO. 6) by laser cladding and friction stir processing (FSP) was studied. A nanometer-sized microstructure consisting of fine carbide (particle size: 100 200 nm) and a grain (grain size: 150 250 nm) was successfully fabricated by the FSP on the laser clad cobalt based alloy. The nanostructured cobalt based alloy (Stellite NO. 6) had an extremely high hardness of about $750 \mathrm{HV}$.
\end{abstract}

Key Words: Friction stir processing, Laser cladding, Cobalt based alloy, Microstructure refinement, Mechanical properties

1. 緒言

一般にステライト系合金と総称されているCo 基合金は, 耐熱性，耐摩耗性および耐酸化性に優れていることから， カッター類の切断工具や金属加工，更には高温下で使用さ れるエンジンバルブの被覆等，幅広い分野で活用されてい る.しかしながら現状では, 高強度化のために大量の合金 元素が添加されており, 既存の焼結法や肉盛溶接法では, 入熱過剩が原因で晶出及び析出する炭化物が粗大化してし まう。そのため, 鋭利な刃先や滑らかな部材表面の形成が 困難であることに加え, 工具の刃先やエッジ部に粗大な炭 化物が存在した場合, 加工中に脱落すると極めて深刻な欠 陷となる。

近年，金属材料の機械的特性を向上させる組織の微細化 技術に多くの関心が集まっている. 各種金属材料の母材結 晶粒を微細化するため, 塑性変形を応用した種々のプロセ スが開発されているが，代表的な強ひずみ加工法（severe

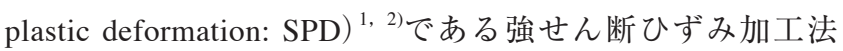
(Equal-Channel Angular Pressing: ECAP) ${ }^{3,4}$ や, 繰り返し重

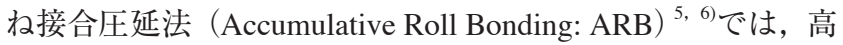
い変形抵抗を有する金属材料への適応が非常に困難である. これに対し, 摩擦攪拌接合 (friction stir welding: FSW) の応用 技術である摩擦攪拌プロセス (friction stir processing: FSP) は 容易に様々な金属材料への適応が可能であり，被改質材に

\footnotetext{
*受付日 平成26年 8 月29日 受理日 平成26年11月16日 平 成23年度秋季全国大会で発表

**正＼cjkstart員＼cjkstart株式会社 AMC Member, AMC Corporation

***正員 大阪大学接合科学研究所 Member, Osaka University Joining and Welding Research Institute

株式会社 AMC AMC Corporation
}

おける任意の領域に強ひずみを導入することができる ${ }^{7-14)}$. これまで我々は，摩擦攪挥プロセスと炭化物の微細化に 効果的であるレーザ処理またはレーザクラッディングの組 合せにより，工具鋼の表面にナノ組織被膜を創製する技術 を提案している ${ }^{15,16)}$. 当該技術では, レーザ照射を用いて 形成させた工具鋼の急冷凝固組織に摩擦攪拌プロセスを施 すことで，炭化物と母材結晶粒のナノサイズ化を達成して いる。また，粉末焼結体でのビッカース硬度が約 $750 \mathrm{HV}$ である冷間工具鋼に対し，摩擦攪拌プロセス後のビッカー ス硬度が約 $900 \mathrm{HV}$ 前後にまで上昇するという結果を得てい る. そこで, Co 基合金においても組織の微細化と炭化物の 均一分散が可能となれば，当該材料を用いた工具の性能や， 鋭利な刃先形成等の加工性が大幅に向上できると思われる. 本研究では, レーザクラッディングを用いて形成した Co 基合金肉盛層に対して摩擦攪拌プロセスを施し，摩擦攪拌 プロセス前の炭化物サイズがプロセス後の組織と硬度に及 す影響について詳細に検討した。

\section{2. 実験方法}

\section{1 供試材}

基板には SKD61 板（17 mm×175 mm×230 mm）を用い， 当該基板の表面にレーザクラッディング被膜を形成させた。 肉盛材料は Co 基合金粉末（山陽特殊製鋼製 ステライト NO.6）を使用した. 肉盛材料の化学組成を Table 1 に示す.合 金元素として, 多量の $\mathrm{Cr}$ と約 $4.5 \mathrm{mass} \%$ の W が添加され ており，冷間から熱間に至るまで幅広い温度領域における 優れた耐摩耗性と耐食性を有している。本研究では工具や 刃物として産業界で汎用されているステライトのNO.6 （480 HV）を用いた。 


\section{2 実験条件}

レーザクラッディングは，同軸クラッディングトーチ (laserline, Type Coax8), 半導体レーザ (laserline, 定格出 力 : $1 \mathrm{~kW}$, 発振波長 : 810 980 nm), 装置の位置制御用口 ボット（安川電機製，DX100），および粉末供給装置で構成 されるレーザクラッディング装置を使用した. クラッディ ング条件はレーザ出力： $600 \mathrm{~W}$, トーチ移動速度： $1000 \mathrm{~mm} / \mathrm{min}$, フォーカス距離 : $12 \mathrm{~mm}$ （ジャストフォーカ ス), レーザ径: $0.9 \mathrm{~mm}$, ラップ数: 20 回とし, シールドガ スとして $8 \mathrm{l} / \mathrm{min}$ の流量でアルゴンガスをフローし，基板表 面に $2 \mathrm{~mm} \times 20 \mathrm{~mm} \times 80 \mathrm{~mm}$ サイズのクラッディング被膜を 形成させた。比較材として，同じ基材の上に TIG 溶接にて 電流：100 A, 電压：10 V, トーチ移動速度： $72 \mathrm{~mm} / \mathrm{min}$, 溶加棒直径 $4.2 \mathrm{~mm}$ の条件を用いてステライトNO.6 肉盛被 膜を形成させた。

次にレーザクラッディング被膜，およびTIG 肉盛被膜に 対して摩擦攪汼プロセスを行った。摩擦攪拌プロセス条件 はツール荷重：3.5 ton, ツール前進角： $3^{\circ}$, ツール回転速 度： $400 \mathrm{rpm}$, ツール移動速度： $400 \mathrm{~mm} / \mathrm{min}$ とし, 摩擦攪挥 プロセス中は $20 \mathrm{l} / \mathrm{min}$ の流量でアルゴンガスをフローさせ た。また，使用したツールの材質は超硬合金であり，ショ ルダ径： $12 \mathrm{~mm}$, プローブ径 : $4 \mathrm{~mm}$ ，プローブ長：0.5 mm とした。なお，摩擦攪拌プロセス後に光学顕微鏡を用いて ツール表面を観察したが，欠けやクラックは見受けられな かった. Fig. 1 にレーザクラッディングおよび摩擦攪拌プロ セスの模式図を示す。

\section{3 評価方法}

摩擦攪拌プロセス前後における，TIG 肉盛被膜およびレ ーザクラッディング被膜の各試料を，摩擦攪拌プロセス方 向に対して垂直な断面で切断・熱間樹脂埋めし，\#400〜

Table 1 Chemical composition of the as-received PS6 powder.

\begin{tabular}{cccccccc}
\hline \multicolumn{1}{c}{} & \multicolumn{1}{c}{} & \multicolumn{3}{c}{ ( mass \% ) } \\
\hline 1.318 & 1.10 & 0.48 & 1.01 & 31.50 & 4.41 & Bal. & 0.58 \\
\hline
\end{tabular}

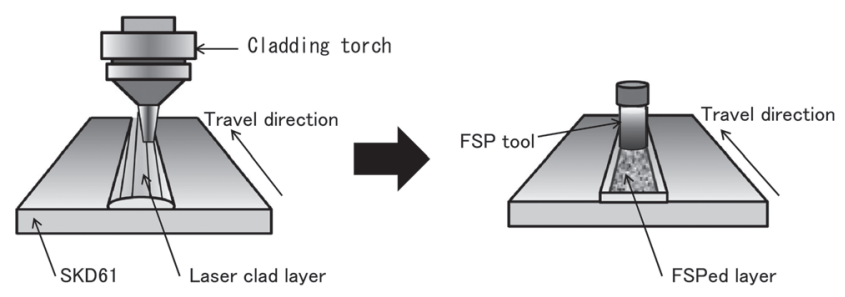

Fig. 1 Schematic of the Laser cladding and the FSP.
\#2000 のエメリー紙およびバフを用いて研磨を行った。当 該各試料に関し，光学顕微鏡（オリンパス株式会社製 BX51RF）および走査型電子顕微鏡（日本電子株式会社製 JSM-7001FA）を用いて断面の微細組織を観察し，炭化物サ イズと母材結晶粒径を透過型電子顕微鏡（日本電子株式会 社製 JEM-4000EX）を用いて評価した。

更に，断面の元素分布および結晶構造を，EDX およびXRD によりそれぞれ評価し, 硬さはマイクロビッカース硬さ試験 機（株式会社フューチュアテック製 FM-ARS10K）を用い て荷重：300 g, 圧子保持時間：15 秒にて測定を行った。

\section{3. 結果および考察}

\section{1 レーザクラッディングにより形成したステライト NO.6 被膜の微細組織}

Fig. 2 に TIG 溶接およびレーザクラッディングにて形成 したステライト被膜の断面 SEM 像を示す。白灰色の領域は 母材結晶粒を示しており，黒灰色の領域は炭化物を示して いる．両被膜は同様に，母材を含んだ大量の炭化物が層状 組織となって母材結晶粒界に偏析し，デンドライト組織を 形成しているが，TIG 肉盛被膜と比較するとレーザクラッ ディング被膜の組織は非常に微細であり，明瞭な差異が確 認できる，炭化物で囲まれた領域を 1 つの母材結晶粒とみ なすと, TIG 肉盛被膜の母材結晶粒径は約 8〜25 $\mu \mathrm{m}$ である のに対し，レーザクラッディング被膜の母材結晶粒径は約 2〜 $4 \mu \mathrm{m}$ であった。両肉盛被膜の炭化物を拡大撮影した SEM 像を Fig. 3 に示す. TIG 肉盛被膜の炭化物サイズは約 7 〜 $15 \mu \mathrm{m}$ であるのに対し，レーザクラッディング被膜では 約 200〜 $300 \mathrm{~nm}$ の微細な炭化物が生成していた。レーザク
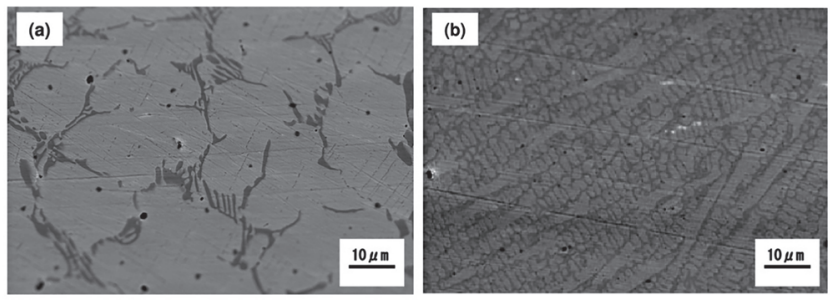

Fig. 2 Microstructure of the TIG (a) and the Laser clad (b) layers.
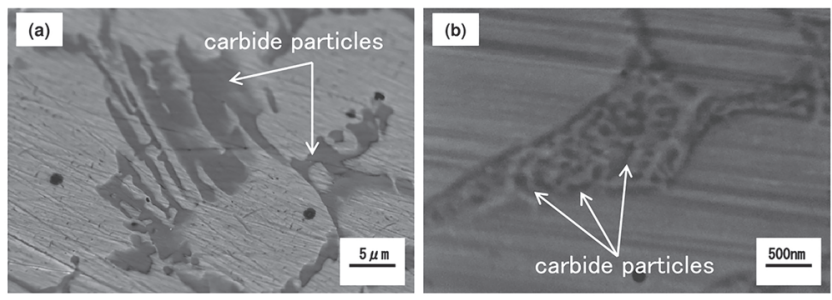

Fig. 3 SEM images of the carbide particles of the TIG (a) and the Laser clad (b) layers. 
ラッデイングにおいては基材表面近傍にレーザをフォーカ スして照射したことで，局所的な急速溶融と急冷凝固が達 成され，母材結晶粒と炭化物に粗大化する時間を与えなか ったことが原因で微細な炭化物が生成したと考えられる。

Fig. 4 にEDX による両被膜の Co と Cr の元素マッピングを 示す. Cr が分布する領域は炭化物，Co が分布する領域は 母材結晶粒を示しており, SEM での組織観察と良い一致が 認められた ${ }^{17,18)}$.

\section{2 摩擦攪捧プロセスによる微細組織の変化}

Fig. 5 に摩擦攪拌プロセス後における TIG 肉盛被膜とレ ーザクラッディング被膜の断面 SEM 像を示す．両被膜共に 摩擦攪拌プロセスの強力な攪拌効果と塑性流動により炭化 物が破砕されて母材結晶粒内に分散しており，デンドライ
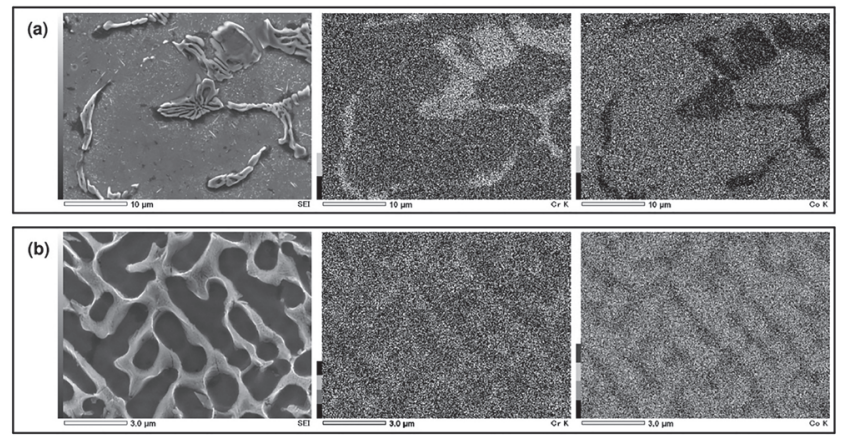

Fig. 4 Element mappings of $\mathrm{Co}$ and $\mathrm{Cr}$ of the TIG (a) and the Laser clad (b) layers.
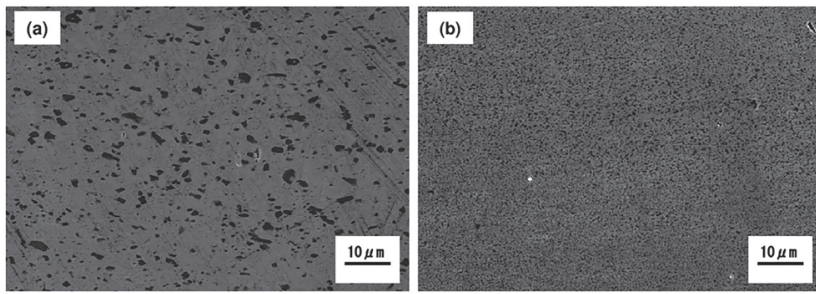

Fig. 5 SEM images of the TIG (a) and the Laser clad (b) layers after the FSP.
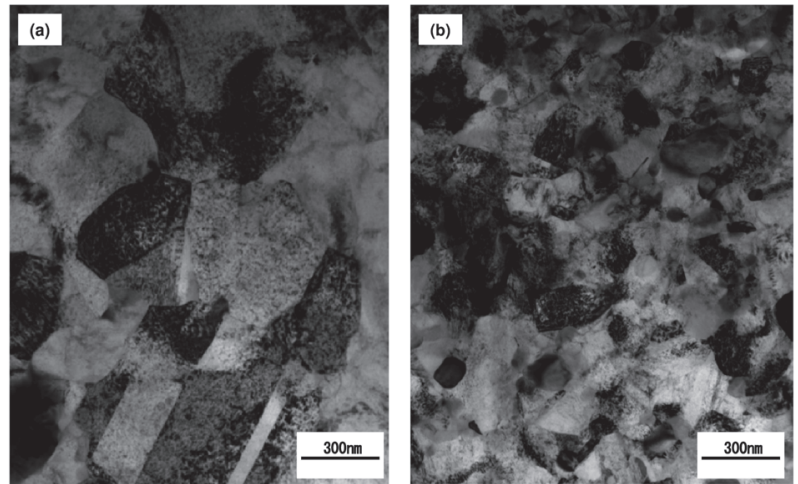

Fig. 6 TEM images of the TIG (a) and the Laser clad (b) layers after the FSP.
卜組織は観察されず，摩擦攪拌プロセス後の両被膜におけ る炭化物量にも大きな差異は見受けられなかった。しかし， 摩擦攪拌プロセスを経ても両被膜における炭化物のサイズ には明瞭な差異が認められる。摩擦攪拌プロセス後におけ る TIG 肉盛被膜の炭化物サイズは約 3 $4 \mu \mathrm{m}$ であるのに対 し，レーザクラッディング被膜では約 100～200 nm となり， レーザクラッディング被膜と比較すると, TIG 肉盛被膜の 炭化物は粗大な状態で分散していることがわかる．Fig. 6 に 摩擦攪拌プロセス後における両被膜の TEM 像を示す。両被 膜の母材結晶粒は，摩擦攪拌プロセスで導入した強ひずみ による再結晶化，及び破砕された炭化物が再結晶化した母 材結晶粒の静的な粒成長をピン止めすることにより，効果 的に微細化が達成されている。ここで，TIG 肉盛被膜の母 材結晶粒径は約 500〜 700 nm，レーザクラッディング被膜で は約 $150 〜 250 \mathrm{~nm}$ となり，摩擦攪拌プロセス後における両被 膜の母材結晶粒径にも差異が認められる。これは，摩擦攪 拌プロセス前における組織の違いが原因であり，摩擦攪拌 プロセス前における炭化物の微細化が母材結晶粒の微細化 に効果的であることを示している.Fig. 7 に両被膜の XRD

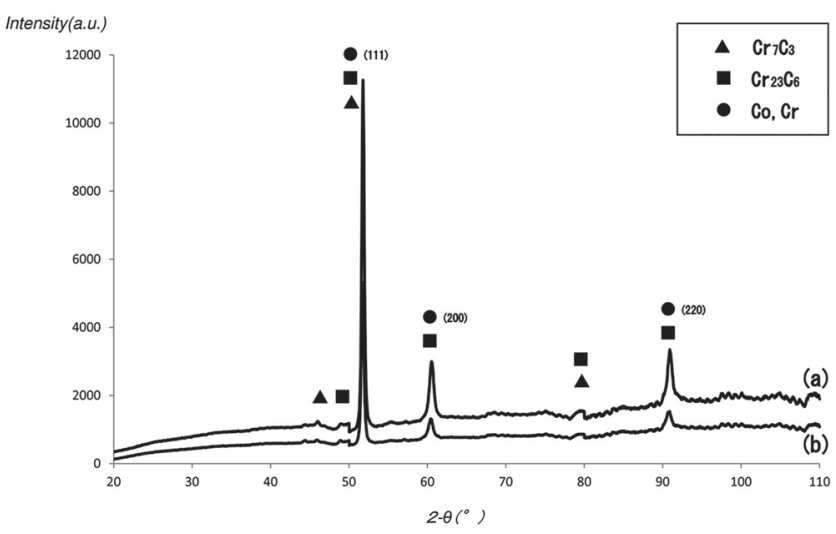

Fig. 7 X-ray diffraction patterns of the TIG (a) and the Laser clad (b) layers after the FSP.

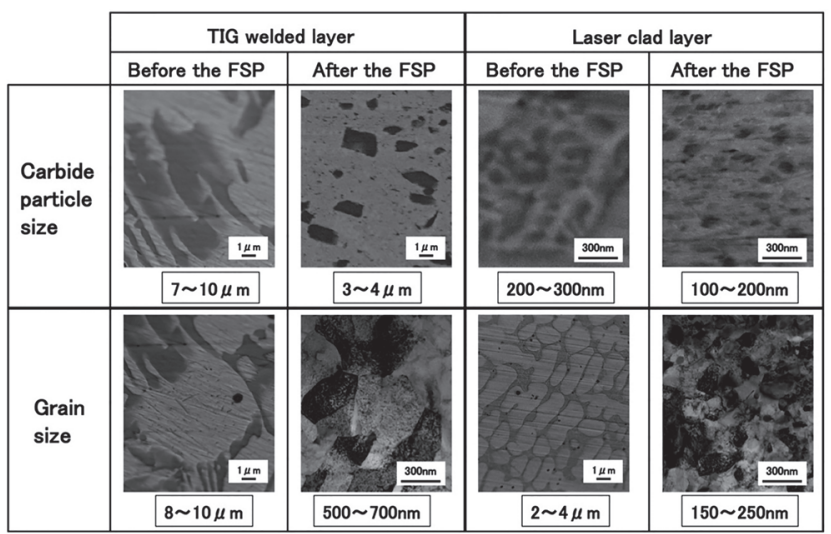

Fig. 8 Carbide particle size and Grain size of the TIG and the Laser clad layers before and after the FSP. 
パターンを示す．両被膜共に母材のCo および炭化物の $\mathrm{Cr}_{7} \mathrm{C}_{3}$ と $\mathrm{Cr}_{23} \mathrm{C}_{6}$ に起因するピークが確認でき $\left.{ }^{19,} 20\right)$ ，両被膜を 構成する相に差異は見受けられなかった。この結果により， 両被膜には形成プロセスに起因する組成に違いはなく，母 材に分散する炭化物のサイズ，及び炭化物間の距離が組織 微細化に大きく影響することを示している。

Fig. 8 にて摩擦攪找プロセス前後における両被膜の組織を 改めて比較する。摩擦攪拌プロセスによって，両肉盛被膜 共に炭化物は約 $1 / 2$ 以下，母材結晶粒は約 $1 / 10$ 以下となっ た。摩擦攪拌プロセスでは炭化物等の硬質粒子を大幅に微 細化することはできないが，強ひずみの導入による再結晶 化と, 分散した炭化物による, 再結晶化した母材結晶粒の 静的な粒成長に対するピン止め効果により，母材結晶粒の 微細化に非常に効果的である ${ }^{21,22)}$.

\section{3 ビッカース硬度評価}

Fig. 9 に摩擦攪挥プロセスを施した表面から深さ方向に測 定したビッカース硬度, Fig. 10 に摩擦攪拌プロセスを施した 表面に対して水平方向に測定したビッカース硬度をそれぞ れ示す。摩擦攪拌プロセスによって硬度が上昇した領域は, 深さ方向は約 $1.5 \mathrm{~mm}$ ，水平方向はプロセスの中心位置から 両側に約 $4 \mathrm{~mm}$ の範囲であった。同じステライトNO. 6 の焼 結体が約 $480 \mathrm{Hv}$ であるのに対し，両被膜は共に摩擦攪挥プ ロセスによって大きな硬度上昇が得られ，摩擦攪拌プロセ 又後の TIG 肉盛被膜では約 $650 \mathrm{Hv}$ ，更にレーザクラッディ ング被膜では約 $750 \mathrm{Hv}$ と高い硬度が確認できた。当該硬度 上昇は母材結晶粒の微細化と, 炭化物の分散の効果によって 得られたものであると考えられ，深さ方向においては両被膜

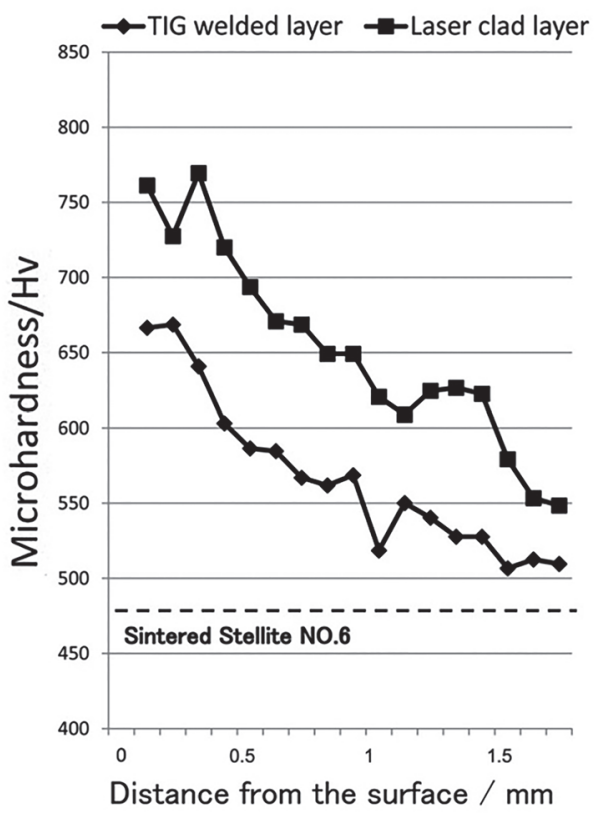

Fig. 9 Microhardness depth profiles on the cross section of the TIG and the Laser clad layers after the FSP.
共にツールの接触面に近い程，当該効果が顕著であった。

硬度の低い母材結晶粒内に少数の粗大な炭化物が距離を 持って存在するより，多量の微細な炭化物が近距離で存在 した方が高硬度化に有利であり，母材結晶粒のサイズと炭 化物間の距離の違いが，両被膜における硬度に差異を与え たと考えられる。また，水平方向の硬度分布において，微細 な炭化物がより均一に分散したレーザクラッディング被膜 に比べ，粗大な炭化物が一部不均一に分散した TIG 肉盛被 膜には硬度に偏りが見受けられた。炭化物は摩擦攪拌プロ セス前に微細化することで母材結晶粒内へより細かく均一 分散し，更に炭化物間の距離が近くなると考えられる。

\section{4. 結}

\section{論}

本研究では，レーザクラッディングを用いて形成した Co 基合金（ステライトNO.6）肉盛層に対して摩擦攪䢁プロセ スを施し，組織と硬度に及す影響について検討した。得ら れた結果を以下に示す。

1）Co 基合金肉盛層に摩擦攪捧プロセスを施すことで，炭 化物は約 $1 / 2$ 以下，母材結晶粒は $1 / 10$ 以下へ微細化が達 成された。

2）Co 基合金肉盛層に対する摩擦攪汼プロセスは，再結晶 化と炭化物によるピン止め効果により，母材結晶粒の微 細化に非常に効果的である.

3） Co 基合金肉盛層に摩擦攪拌プロセスを施すことで，通 常の焼結体の硬度 $480 \mathrm{HV}$ よりも高硬度となり，TIG 肉

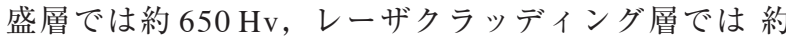
$750 \mathrm{Hv}$ の值が得られた。

4）Co 基合金肉盛層の組織微細化と高硬度化には，急冷凝

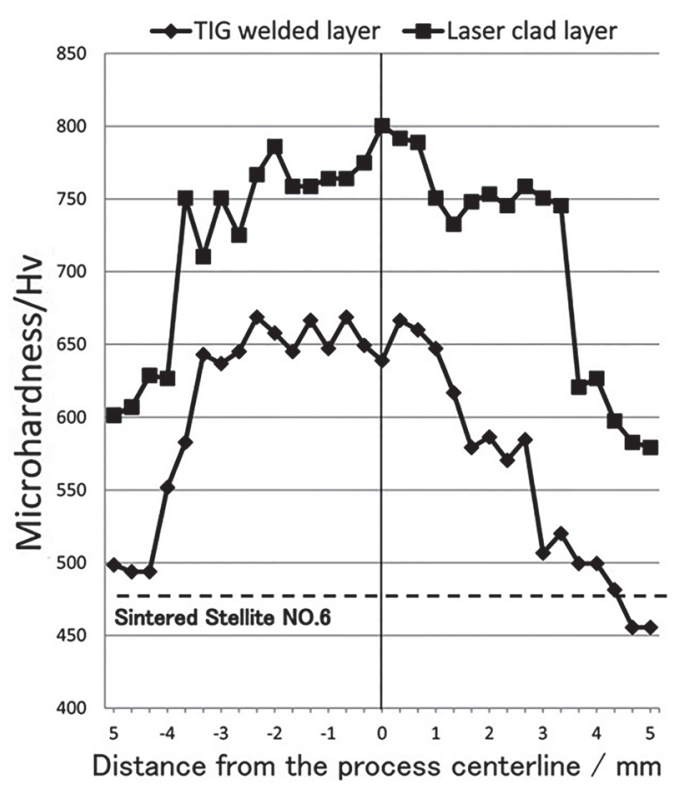

Fig. 10 Microhardness horizontal profiles on the cross section of the TIG and the Laser clad layers after the FSP. 
固プロセスを用いた摩擦攪拌プロセス前の炭化物微細化 が効果的である。

\section{参 考 文 献}

1) R.Z. Valiev, N.A. Krasilnikov, N.K. Tsenev, Mater. Sci. Eng. A 137 (1991) 35 .

2) M. Furukawa, Z. Horita, M. Nemoto, R.Z. Valiev, T.G. Langdon, Acta Mater. 44 (1996) 4619

3) Z. Horita, T. Fujinami, T.G. Langdon, Mater. Sci. Eng. A 34-41 (2001) 318.

4) Y. Gang, Y, Fengshi, Mater. Sci. Forum. 667/669 (2011) 879-884.

5) Y. Saito, N. Tsuji, H. Utsunomiya, T. Sakai, R.G. Hong, Scripta Mater. 39 (1998) 1221.

6) N. Hansen, X. Huang, R. Ueji, N. Tsuji, Mater. Sci. Eng. A 387-389 (2004) 191.

7) K. Ohishi, T.R. Mcnelley, Metall. Trans. A 35A (2004) 2951-2961.

8) J.Q. Su, T.W. Nelson, C.J. Sterling, Scripta Mater. 52 (2005) 135140 .

9) D.C. Hofmann, K.S. Vecchio, Mater. Sci. Eng. A 402 (2005) 234241.

10) H.J. Liu, H. Fujii, K. Nogi, Mater. Sci. Tech. 20 (2004) 399-402.
11) H. Fujii, Y.G. Kim, T. Tsumura, T. Komazaki, K. Nakata, Mater Trans. 47 (2006) 224-232.

12) Y. Morisada, H. Fujii, T. Mizuno, G. Abe, T. Nagaoka , M. Fukusumi, Surf. Coat. Tech. 204 (2010) 2459-2464.

13) Y. Morisada, H. Fujii, T. Mizuno, G. Abe, T. Nagaoka , M. Fukusumi, Surf. Coat. Tech. 204 (2009) 386-390.

14) T. Nagaoka, H. Watanabe, M. Fukusumi, T. Mizuno, G. Abe, Y. Morisada, H. Fujii. Mater Sci Forum. 735 (2012) 422-426.

15) Y. Morisada, H. Fujii, T. Mizuno, G. Abe, T. Nagaoka, M. Fukusumi, Mater. Sci. Eng. A 157-162 (2009) 505.

16) Y. Morisada, H. Fujii, T. Mizuno, G. Abe, T. Nagaoka, M. Fukusumi, Surf. Coat. Tech. 205 (2011) 3397-3403.

17) P.D. Wood, H.E. Evans, C.B. Ponton, Tribology International, 44 (2011) 1589-1597.

18) Iulian Radu, D.Y. Li, Tribology International, 40 (2007) 254-265.

19) R. Ahmed, A. Ashraf, M. Elameen, N.H. Faisal, A.M. El-Sherik, Y.O. Elakwah, M.F.A. Goosen. Wear. 174 (1994) 81-91.

20）徐国建，沓名宗春，山田勝重，溶接学会論文集，第23巻，第 2 号，(2005) 286-295

21) Y. Morisada, H.Fujii, T. Nagaoka, M. Fukusumi, Scripta Mater. 55 (2006) 1067-1070

22) Y. Morisada, H. Fujii, T. Nagaoka, M. Fukusumi, Mater. Sci. Eng. A 433 (2006) 50-54. 